\title{
Prilog unapređenju postupaka za održavanje pomorskih karata i navigacijskih publikacija
}

\author{
Zlatimir Bićanić, Josip Kasum i Zvonko Gržetić
}

\begin{abstract}
Teškoće u provođenju postupaka za održavanje pomorskih karata i navigacijskih publikacija (reambulacija u procesima hidrografskih organizacija) izravno utječu na usklađenost podataka na pomorskim kartama i navigacijskim publikacijama sa stvarnim stanjem u naravi. Ovaj je rad pokušaj doprinosa povećanju djelotvornosti reambulacijskih postupaka i u konačnici, višem stupnju točnosti dokumenata u izravnoj službi sigurnosti plovidbe. Predlažu se stanovite promjene u neposrednom terenskom radu koji obuhvaća akvatorij hidrografske izmjere, te u djelatnostima hidrografskih služba u izboru i obradama podataka iz reambulacija. Doprinos praksi svakako je određivanje odnosa reambulacije i hidrografske izmjere. Primjeren prostor posvećuje se razgraničenju redovitih reambulacijskih i izvanrednih postupaka.
\end{abstract}

Ključne riječi: reambulacija, hidrografija, izmjera,

\section{Contributions to Advancement of Updating Procedures of Sea} Charts and Sea Publlications

Difficulties in carrying out the revision procedures (reambulation in the hydrographic organisation processes) have a direct influence on the accordance of information on charts and nautical publications with the real situation in nature. This paper aims to help towards a greater effectiveness of revision procedures and finally to bring about a higher level of accuracy of documents related to the safety at sea. It proposes to introduce some changes in the field work covering the sea area of the hydrographic survey, as well as in the activities of hydrographic organizations when selecting and processing the revision data. A valuable contribution to the practice is that it determines the relation between revision and hydrographic survey. Due space is devoted to the determining of boundaries between regular revision procedures and additional procedures.

Key words: reambulation, hydrography, survey

\section{UVOD}

Tema ovog rada su prijedlozi za unapređenje postupaka za održavanje pomorskih karata i navigacijskih publikacija (reambulacija; B. Klaić, 1986.), kojima koriste se hidrografske službe u provjeravanju stupnja podudarnosti podataka na pomorskim kartama i navigacijskim publikacijama sa stvarnim stanjem u prirodi. Temelj za izradu pomorske karte je, međunarodnim preporukama standardizirana hidrografska izmjera. Reambulacija je 
nestandardiziran pomoćni postupak, važan za praktičnu provjeru vjerodostojnosti pomorske karte koja je i danas temeljno sredstvo u pomorskoj navigaciji. Kao nestandardiziran postupak različito se provodi u različitim hidrografskim službama. Izravna posljedica je različnost podataka za održavanje.

Oni se razlikuju prema čestoći i točnosti prikupljanja, obliku i sl., što izravno utječe na promjene stanja točnosti podataka koji se prikazuju na pomorskim kartama i u navigacijskim publikacijama. Svrha rada prilog je pronalaženju načina povećanja stupnja usuglašenosti podataka koje sadrže pomorske karte i navigacijske publikacije sa stvarnim stanjem u prirodi, kao i međusobno.

Reambulacija je postupak prikupljanja, analize i obrade pomorskih sigurnosnih informacija i podataka o morskim plovidbenim područjima radi održavanja pomorskih karata i navigacijskih publikacija. Valja ga razvrstati na terenske i djelatnosti u hidrografskoj ustanovi.

Terenske djelatnosti obavljaju se u području isključivog obuhvata hidrografske izmjere (morska plovidbena područja). Koriste se različita prenosiva tehničko/tehnološka pomagala (uređaji, instrumenti i oprema za određivanje i mjerenje pozicija, dubina, visina, daljina, foto i video snimanja itd.; (E. Kiely, 1979.). Reambulaciju može obavljati tim ili pojedinac (skupna/pojedinačna), a korištenje hidrografskog broda nije nužno. ${ }^{1}$

Djelatnosti u hidrografskim službama obuhvaćaju analizu i obradu rezultata reambulacije, nakon čega se izabiru podaci za održavanje pomorskih karata i navigacijskih publikacija (Katalog, 1998.). Analizom, odabirom i obradom podataka završava se reambulacijski postupak. Odabrani podaci tiskaju se u Oglasima za pomorce.

Postupkom reambulacije, različnosti između stvarnosti i informacijskog sadržaja pomorskih karata i navigacijskih publikacija, mogu se svesti na manju mjeru.

\section{VRSTE REAMBULACIJA I RAZINA TOČNOSTI}

Reambulacijom se provjerava usuglašenost stvarnoga stanja sa stanjem koje se prikazuje na pomorskim kartama i u navigacijskim publikacijama. Stanje koje se prikazuje, temelji se na rezultatima hidrografske izmjere (uključujući i proces održavanja). Stoga je opravdan prijedlog za razvrstavanje reambulacije (sukladno razvrstavanju hidrografske izmjere, Tab. 1) na reambulaciju: za posebne namjene, te reambulaciju prve, druge i treće kategorije.

Postupak reambulacije za posebne namjene odnosi se na područja, koja u pogledu dubine predstavljaju potencijalnu opasnost za plovidbu (luke, sidrišta i kanali).

Prva kategorija reambulacije odnosi se na luke, prilazne kanale, plovidbene rute koje se preporučaju, kopnene kanale i obalne površine s gustim pomorskim prometom, gdje dubine nisu opasne za pomorsku plovidbu, a manje su od $100 \mathrm{~m}$.

Druga kategorija reambulacije odnosi se na vodene površine s dubinama manjima od $200 \mathrm{~m}$, koje ne obuhvaća posebna reambulacija i prva kategorija u područjima u kojima je općeniti opis batimetrijskih podataka dostatan za sigurnu plovidbu. 
Treća kategorija odnosi se na sve druge površine, koje ne obuhvaća reambulacija za posebne namjene, prva i druga kategorija, a obuhvaća dubine veće od 200m.

Tab. 1. Kategorije reambulacije

Tab. 1 Revision categories

\begin{tabular}{|c|c|c|c|c|}
\hline KATEGORIJA & POSEBNA & PRVA & DRUGA & TREĆA \\
\hline Tipična područja & $\begin{array}{c}\text { Luke, sidrišta, } \\
\text { kritični kanali } \\
\text { s minimalnom } \\
\text { dubinom ispod } \\
\text { kobilice }\end{array}$ & $\begin{array}{c}\text { luke, prilazni } \\
\text { kanali, } \\
\text { preporučene } \\
\text { plovidbene rute } \\
\text { i neka obalna } \\
\text { područja s } \\
\end{array}$ & $\begin{array}{c}\text { Područja } \\
\text { neobuhvaćena } \\
\text { posebnom } \\
\text { izmjerom } \\
\text { i prvom } \\
\text { dubinama do } \\
\text { kategorijom s } \\
\text { dubinama do } \\
\end{array}$ & $\begin{array}{c}\text { Područja } \\
\text { otvorenog mora, } \\
\text { neobuvaćena } \\
\text { posebnom } \\
\text { izmjerom, } \\
\text { prvom i drugom } \\
\text { kategorijom }\end{array}$ \\
& & $100 \mathrm{~m}$ & $200 \mathrm{~m}$ & \\
\hline
\end{tabular}

Radi razlikovanja mjerenja u reambulaciji i u hidrografskoj izmjeri, valja koristiti odrednicu kontrolna mjerenja. Za sve kategorije reambulacije valja primijeniti jednake standarde točnosti kontrolnih mjerenja. Određuju se prema važećim standardima izmjere (IHO, 1998.).

Točnost kontrolnih mjerenja pozicija mora biti jednaka zahtjevima horizontalne točnosti posebne kategorije hidrografske izmjere.

Točnost kontrolnih mjerenja dubina mora biti jednaka zahtjevima točnosti mjerenja reduciranih dubina s $95 \%$ pouzdanosti posebne kategorije hidrografske izmjere.

U uskom priobalnom pojasu, hidrografija se nadopunjuje s topografskim podacima. Prikupljaju ih i njima raspolažu geodetske uprave i srodne službe. Stoga se ne nalaze zahtjevi za točnošću mjerenja visina u standardima izmjere.

Točnost kontrolnih mjerenja visina u svezi podataka za održavanje, mora biti jednaka najvišem stupnju točnosti trenutačno raspoloživih tehnologija prijenosnih uređaja za mjerenje visina.

Točnost kontrolnih mjerenja udaljenosti između pozicija, za svaku poziciju mora biti jednaka zahtjevima horizontalne točnosti posebne kategorije hidrografske izmjere (J. Kasum, 2002.).

\section{ODNOS REAMBULACIJE I HIDROGRAFSKE IZMJERE}

Hidrografska izmjera provodi se prema važećim standardima(IHO, 1998.). Dobiveni rezultati (hidrografski podaci), unose se u nova izdanja pomorskih karata i navigacijskih publikacija. Također služe i za ispravljanje postojećih izdanja.

Temeljem rezultata kontrolnih reambulacijskih mjerenja ne može se izdati novo izdanje pomorske karte i navigacijske publikacije (IHO, 1994.). Rezultati kontrolnih reambulacijskih mjerenja služe isključivo za prikupljanje podataka za održavanje 
pomorskih karata i navigacijskih publikacija i druge potrebe hidrografskih služba. Druge potrebe odnose se na djelatnosti koje se izravno ne povezuju s izdavanjem pomorskih karata i navigacijskih publikacija (npr. specifični zahtjevi vojnih vlasti i tržišta). Kontrolna mjerenja izvodi reambulator postupkom reambulacije. Reambulacija ne može zamijeniti hidrografsku izmjeru. U prvom redu odnosi se na provjeru točnosti i usuglašenosti podataka za održavanje pomorskih karata i navigacijskih publikacija, nakon obavljene hidrografske izmjere i drugih postupaka hidrografskih služba, kada je utjecaj nastalih promjena toliki da ju valja provesti. Rezultat reambulacije nije uvijek ispravljanje ili potvrda točnosti podataka, već može rezultirati i uočavanjem potrebe za novom hidrografskom izmjerom.

Odnos hidrografske izmjere i reambulacije prikazuje se na slici 1. Teoretski se poljem točnosti u hidrografiji može smatrati površina (Ppth). Jednaka je sumi konačnog broja pojedinačnih površina.

Pojedinačna površina je produkt točnosti hidrografskog podatka (Thpi) i ispravka u vremenu t (mhi).

$$
\begin{gathered}
P_{p t h}=\left(T h p_{1} m h_{1}\right)+\left(T h p_{2} m h_{2}\right)+\ldots . .\left(T h p_{n} m h_{n}\right) \\
P_{p t h}=\sum_{\mathrm{i}=1}^{n}\left(T h p_{\mathrm{i}} \cdot m h_{\mathrm{i}}\right)
\end{gathered}
$$

Teoretski se poljem točnosti u reambulaciji može smatrati površina (Pptr). Jednaka je sumi konačnog broja pojedinačnih površina.

Pojedinačna površina je produkt točnosti reambulacijskog podatka (Trpi) i ispravka u vremenu $\mathrm{t}$ (mri):

$$
\begin{gathered}
P_{p t r}=\left(T r p_{1} m r_{1}\right)+\left(T r p_{2} m r_{2}\right)+\ldots . .\left(T r p_{n} m r_{n}\right) \\
P_{p t r}=\sum_{\mathrm{i}=1}^{n}\left(T r p_{\mathrm{i}} \cdot m r_{\mathrm{i}}\right)
\end{gathered}
$$

Površine (Ppth) i (Pptr) valja usporediti. Mogući rezultati usporedbe površina polja točnosti (Ppth) i (Pptr) u nekom trenutku su:

$$
\begin{aligned}
& \text { 1. } P_{p t h}>P_{p t r} \\
& \text { 2. } P_{p t h}=P_{p t r} \\
& \text { 3. } P_{p t h}<P_{p t r}
\end{aligned}
$$

U prvom slučaju, kada je polje točnosti hidrografije veće od polja točnosti reambulacije, vrijedi da je točnost u području hidrografije, pa reambulacija nema smisla.

U drugom slučaju, kada su polja točnosti hidrografije i reambulacije iste površine, može se uočiti točka susreta (S) točnosti tehnologija hidrografije i reambulacije (J. Kasum, 2002.).

U trećem pak slučaju, kada polje točnosti reambulacije postaje veće od polja točnosti hidrografije, vrijedi da se stvara područje povećanja točnosti. U tom području 


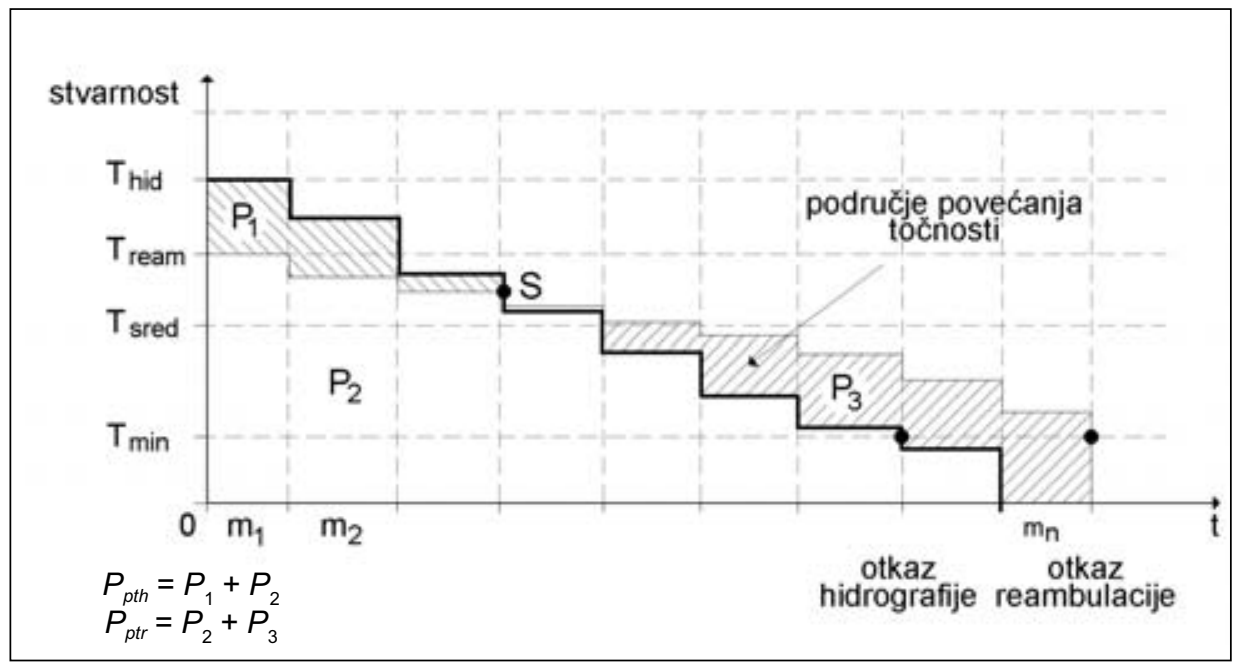

S1.1. Susret tehnologija hidrografske izmjere i reambulacije

Fig. 1 Encounter of hydrographic survey and revision technologies

reambulacija opravdava svoju svrhu. Ona povećava točnost podataka u pomorskim kartama i navigacijskim publikacijama. Pomak točke susreta tehnologija ovisi o podacima na koje se odnosi. Polje povećanja točnosti prvo se javlja kod kratkoročnih, zatim dugoročnih i statičkih podataka.

\section{POSTUPCI U REAMBULACIJI}

Analiza informacijskog sadržaja oglasa za pomorce ${ }^{2}$ različitih izdavača, pokazuje da se u njima objavljuju raznoliki podaci za održavanje pomorskih karata i navigacijskih publikacija. Rezultat su obrade raznovrsnih mjerenja i drugih načina prikupljanja podataka, koje provode djelatnici hidrografskih služba reambulacijom (sl. 2.), u okviru svojih redovitih radnih postupaka (sl. 4).

Osoba koja sustavno provodi reambulaciju pojedinog područja je reambulator i valja ga razlikovati od osobe koja obavlja hidrografsku izmjeru (hidrograf) ${ }^{3}$. Reambulator mora zadovoljiti određene uvjete, standarde obrazovanja, vladati multidisciplinskim znanjima i imati stanovito plovidbeno iskustvo. Znanja iz područja znanstvenih disciplina i vještina, navigacije, hidrografije, kartografije, pomorskih komunikacija, pomorske elektronike, informatike, izdavaštva i drugog, stječe unutar hidrografskih služba i u plovidbi hidrografskim brodom. Kao potvrdu valja razmotriti i polaganje posebnog stručnog ispita (J. Kasum, 2002., S. Oshima, 1998.).

Podaci za održavanje, koje obuhvaća reambulacija, su vrlo brojni i raznovrsni. Za sigurnost plovidbe svaki podatak informacijskog sadržaja pomorskih karata i navigacijskih publikacija nije jednako važan. Stupanj važnosti procjenjuje reambulator. Stoga se predlaže određivati ocjenu navigacijske važnosti $(\mathrm{Kn} ;$ sl. 3) podatka/skupine podataka, što se u praksi ne uobičava. 


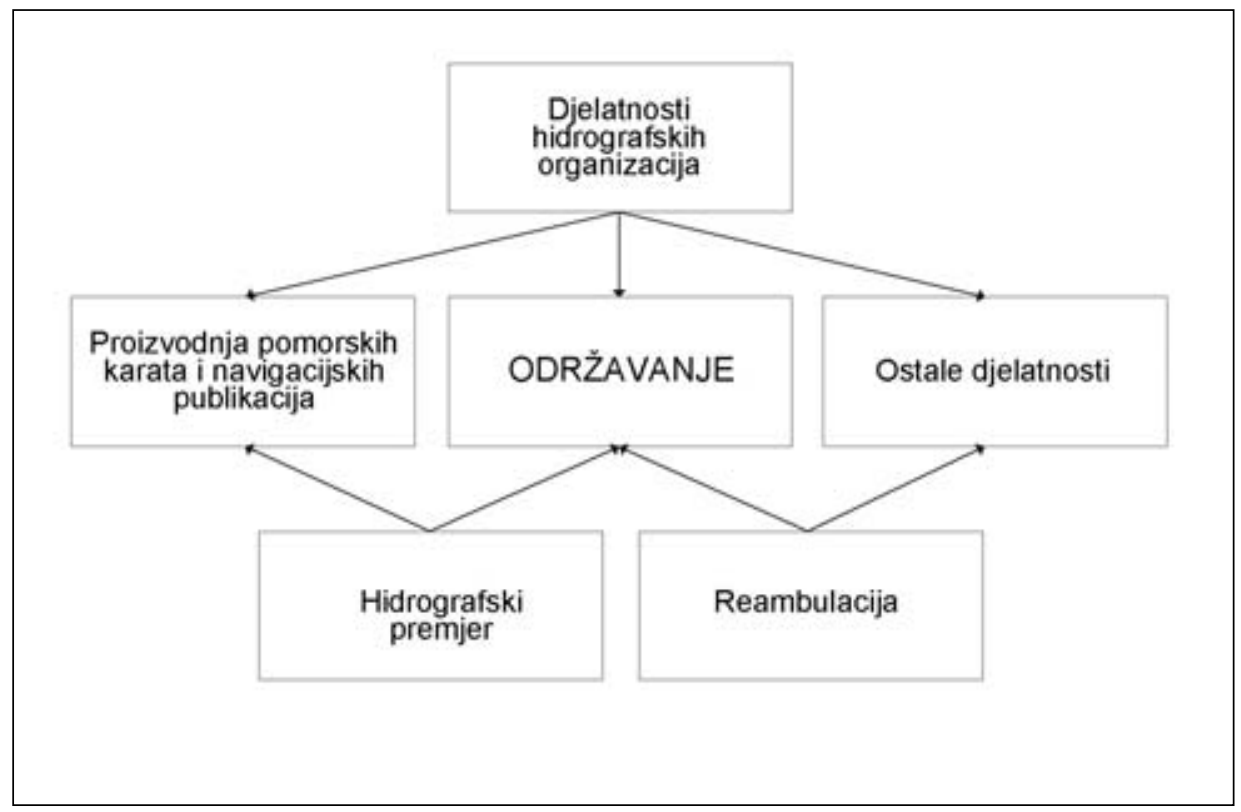

S1.2. Reambulacija i hidrografske službe

Fig. 2 Revision and hydrographic organizations

S razine sigurnosti plovidbe (kao i za postupak reambulacije), mjerilima za ocjenjivanje navigacijske važnosti drže se:

- vrsta reambulacije koja se primjenjuje na područje čiji se podatak/podaci provjeravaju,

- svojstva podatka/skupine podataka glede sigurnosti plovidbe i

- dubine.

Prvo mjerilo odnosi se na kategorije reambulacije. Njima se općenito određuje važnost podatka/skupine podataka za cijelo područje. Drugo se odnosi na točnije određivanje važnosti svojstva podatka/skupine podataka promatranog područja glede sigurnosti plovidbe, a treće izuzetno važno, je dubina. Kao i u hidrografskoj izmjeri, odnosi se na dubine veće i manje od $100 \mathrm{~m}$.

Ocjene navigacijske važnosti podatka/skupine podataka vrijedne su radi donošenja upravljačkih odluka. U postupku reambulacije predlaže se određivanje u rasponima: nevažan (1), manje važan (2), važan (3), srednje važan (4), vrlo važan (5) i izuzetno važan (6).

Najnižu ocjenu (1) dodjeljuje se u područjima iz posebne, prve, druge i treće kategorije reambulacije, kada svojstva podatka/skupine podataka nisu presudna za sigurnost plovidbe ili kada su izvan svih kategorija reambulacije.

Ocjena manje važan (2) dodjeljuje se u područjima iz treće kategorije reambulacije, kada su svojstva podatka/skupine podataka presudna za sigurnost plovidbe i kada su dubine veće od $100 \mathrm{~m}$. 


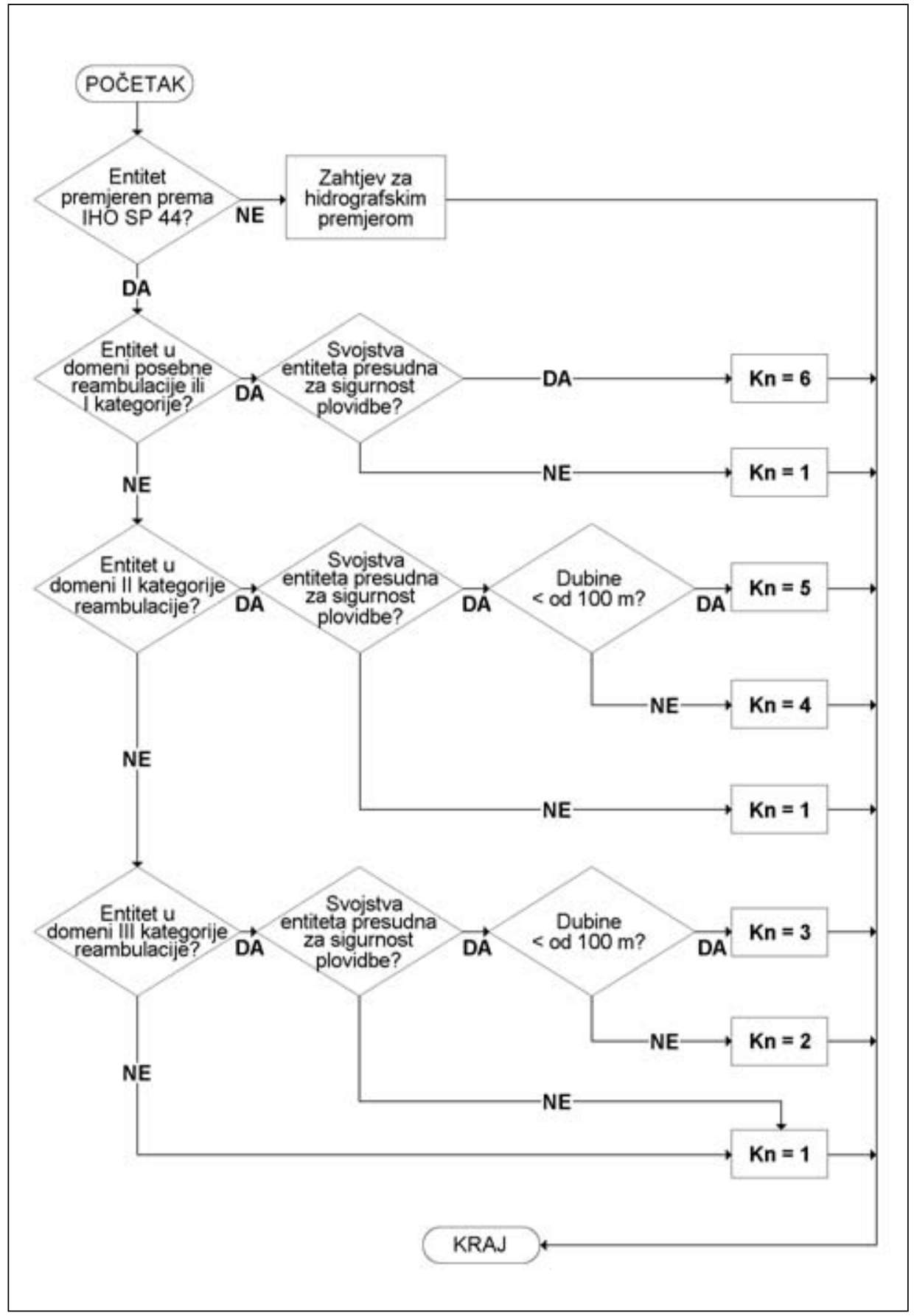

S1. 3. Algoritam za određivanje ocjene navigacijske važnosti entiteta

Fig. 3 Algorithm for determining evaluation of entity's navigational importance 
Ocjena važan (3) dodjeljuje se u područjima iz treće kategorije reambulacije (svojstva podatka/skupine podataka presudna su za sigurnost plovidbe; dubine manje od $100 \mathrm{~m}$ ).

Srednje važan (4) dodjeljuje se se u područjima iz druge kategorije reambulacije, kada su svojstva podatka/skupine podataka presudna za sigurnost plovidbe (dubine veće od $100 \mathrm{~m}$ ).

Ocjena vrlo važan (5) dodjeljuje se u područjima iz druge kategorije reambulacije, kada su svojstva podatka/skupine podataka presudna za sigurnost plovidbe i kada su dubine manje od $100 \mathrm{~m}$.

Izuzetno važan (6) dodjeljuje se u područjima iz posebne i prve kategorije reambulacije, kada su svojstva podatka/skupine podataka presudna za sigurnost plovidbe.

Radi preglednosti algoritma za određivanje ocjene navigacijske važnosti entiteta (sl. 3), umjesto odrednica svojstva podataka ili skupine podataka koristi se odrednica svojstva entiteta. Svaki entitet pomorske karte i/ili navigacijske publikacije određuje se jednim ili s više podatka (npr. pozicije, dubine, visine i druga svojstva mora). To su svojstva entiteta.

Najvažnije podatke za održavanje ispravnosti pomorskih karata i navigacijskih publikacija dobije se određivanjem i mjerenjima pozicija, dubina, nekih hidroloških značajka morske vode, visina i udaljenosti (K. T. Adams, 1942.).

Određivanje položaja (pozicije) vrsta je kontrolnih mjerenja koja izvodi reambulator i ona se provode kod svih entiteta. Ova mjerenja obuhvaćaju provjeru pozicija entiteta i mjerenja potrebnih trenutačnih pozicija, ovisno o postavljenomu cilju. Radi olakšanja obrade i smanjivanja pogrešaka u tumačenju prikupljenih podataka, predlaže se bilježenje pozicije mjesta na kojima se izvode kontrolna mjerenja i snimanja, za što valja koristiti odrednicu referentna pozicija.

Dubina mora je vertikalna udaljenost između trenutačne morske razine $\mathrm{i}$ dna. Za navigaciju je neiskoristiv podatak o dubini, ako se ona nije odredilo u prostoru s dvije koordinate. Pri hidrografskom mjerenja dubina, u području hidrografske izmjere kotiraju se pojedine točke na dnu. Dubine se određuju s dvije koordinate u koordinatnom sustavu. Zbog utjecaja morskih mijena bilježi se i vrijeme u kojem se se obavilo mjerenja. Hidrografskom izmjerom, dubine se mjere prema planiranim linijama ili prema rasutim točkama. Mjerenje prema rasutim točkama obavlja se na ograničenim područjima iz kategorije posebne izmjere, uz operativne lučke obale i sl., u svakom slučaju, u navigacijski teškim područjima/mjestima.

Podvodni se reljef (B. Jovanović, 1975.) kartografski oblikuje temeljem podatka o izmjerenim dubinama i njihovim pozicijama. U podvodnom reljefu razlikuju se: žal, šelf, nagib (podina ili slaz) i abisal (dubokomorsko dno). Žal (litoral) ili obalno područje je uz obalnu crtu. Pod stalnim je mehaničkim utjecajem morske vode. Za visokih voda neki dijelovi Žala su ispod, a za niskih iznad morske movršine (grebeni, plićine, hridi i sprudovi). Šelf ili kontinentski rub je podloga na kojoj je kopno. Proteže se do prosječno 200m dubine.

Nagib je dio podvodnog reljefa koji se spušta od šelfa do najvećih dubina. Abisal obuhvaća najdublje morske vode i zauzima približno $78 \%$ ukupne površine morskog dna (M. Buljan i M. Zore-Armanda, 1971.). 
Na prirodno oblikovanje podvodnog reljefa utječu i morske struje. One donose i premještaju talog, te stvaraju područja s promjenljivim dubinama. Takova područja mogu biti opasna za plovidbu.

Pri kontrolnim mjerenjima dubina u lukama, marinama i lučicama, na mjestima gdje su za sigurnost plovidbe znatna odstupanja dubina (dubine uz pristane, glavu, korjen gata i sl.), predlaže se označavanje geodetskih točaka koje služe za reambulaciju. Na taj bi se način osiguralo točno poznavanje pozicije na kojoj se obavilo kontrolno mjerenje dubina s ciljem ponovnog dolaženja i mjerenja na istoj točki. Kontrolna mjerenja dubina odnose se na mjerenja uz gatove, u uvalama, potkopima, lukama, lučicama, marinama, objektima za marikulturu i sl.

Kontrolna mjerenja drugih svojstava mora odnose se na mjerenja struja, slanosti, tipa i vrste morskoga dna, te položaje i pozicije podvodnih objekata (podrtina potonulih brodova, arheoloških ostataka, odlagališta streljiva, odlagališta raznih vrsta otpada i sl.)

Stvarni položaji podmorskih kabela (energetskih, svjetlovodnih i inih), te raznih cjevovoda, odstupaju od prikazanih na pomorskim kartama i publikacijama. Polagač kabela, cjevovoda i sl. mora prijavljivati projektom predviđene ulazne i izlazne pozicije, te projektiran položaj kabela i/ili cjevovoda. Ova se obveza ne ispunjava redovito. Osim toga, poteškoća je što se u stvarnosti (nakon polaganja instalacija), stvarni položaji polaganja ne podudaraju s onima koje se predvidjelo izvedbenim projektima. Hidrografske službe koriste podatke iz projektne dokumentacije, pa to može rezultirati netočnim podatkom na pomorskoj karti i/ili u navigacijskoj publikaciji.

Predlaže se, nakon polaganja kabela, cjevovoda ili sličnih instalacija u more, obvezno obaviti reambulaciju područja. Cilj je usuglašavanje položaja sa stvarnim stanjem, te s podacima na pomorskim kartama i u navigacijskim publikacijama.

Zbog izgradnje visine obala se mijenjaju (pravna i bespravna nasipanja, dograđivanja, pregrađivanja, jaružanja i sl.). Pravno, postoje obveze javljanja promjena u okolišu na kopnu, geodetskim službama. ${ }^{4}$ Dio područja nadležnosti geodetskih služba podudara se s dijelom hidrografije u kojemu se ona nadopunjuje s topografskim podacima. Geodetske službe ne obavljaju nadzor promjena čestoćom potrebnom hidrografskim službama. Hidrografske se službe redovito i na odgovarajući način ne obaviještavaju o svim promjenama, pa se i nakon hidrografske izmjere reambulacijom moraju provjerati visine svjetionika, obalnih $\mathrm{i}$ lučkih svjetala, svijetlećih oznaka, drugih oznaka (urušavanja, nadogradnje i sl.) i istaknutih (markantnih) objekata (nadogradnje, dogradnje, pravne, bespravne i sl.).

Kontrolna mjerenja duljina (topografija obale) odnose se na duljine između postojećih i produljenih gatova, dizalica i obale, istezališta i drugih objekata, priključaka za vodu i struju, raznih odlagališta i sl. U cilju smanjivanja troškova poslovanja hidrografskih služba i povećanja razine informacijskog dijela sigurnosti plovidbe, u građevinskim projektima koji se odnose na kopno (u obuhvatu hidrografske izmjere), valja predvidjeti troškove za reambulacije.

Dio podataka za održavanje pomorskih karata i navigacijskih publikacija prikuplja se i postupcima iz kontrolnih snimanja, vizualnog motrenja i usmenim priopćenjima (interview). Kontrolna snimanja obuhvaćaju snimanja luka, lučica, uvala, svjetionika, gatova, pristana, 
markantnih objekta, potkopa, prolaza i sl. Novonastala situacija na terenu ne bi se smjela prikazivati digitalnom ili analognom fotografijom dobivenom grafičkom obradom više različitih digitalnih ili analognih fotografija snimljenih u različitom vremenu (fotomontaža). Novonastala situacija mora se prikazati novom, izvornom i jedinstvenom snimkom.

Do pojave dijela pogrešaka u navigacijskim publikacijama, dolazi se pri grafičkoj obradi (grafičko naljepljivanje slika/crteža novih gatova, dodavanje ili brisanje zvonika, srušenih zgrada i sl.). U navigacijskim bi publikacijama valjalo navoditi podatke o poziciji snimanja (fotografiranja) prilaza objektima, važnima za navigaciju i sigurnost plovidbe. Poziciju valja zabilježiti pokraj oznake smjera iz kojeg se obavilo snimanje.

Kontrolnim vizualnim motrenjima promatra se obala, obalni rub, okoliš i okolica luka, lučica, pristana i sl. Važno je uočavati pojedinosti koje mogu utjecati na sigurnost plovidbe. Razgovor se obavlja s privatnim i službenim osobama (lučke i vojne vlasti, državna tijela, geodetske uprave, ribari, pomorci, lokalno stanovništvo i sl.). Prikupljene informacije za iste objekte razlikuju se sadržajno i opisno, ovisno o tomu tko ih daje i o tomu tko i na koji način prikuplja obavještenja. Zbog tipiziranja pitanja i odgovora predlaže se razviti univerzalne - tipske obrasce za reambulaciju (J. Kasum, 2002.).

Hidrografske službe provjeravaju točnost informacijskog sadržaja na pomorskim kartama i u navigacijskim publikacijama. Podaci koji se prikupe hidrografskom izmjerom i

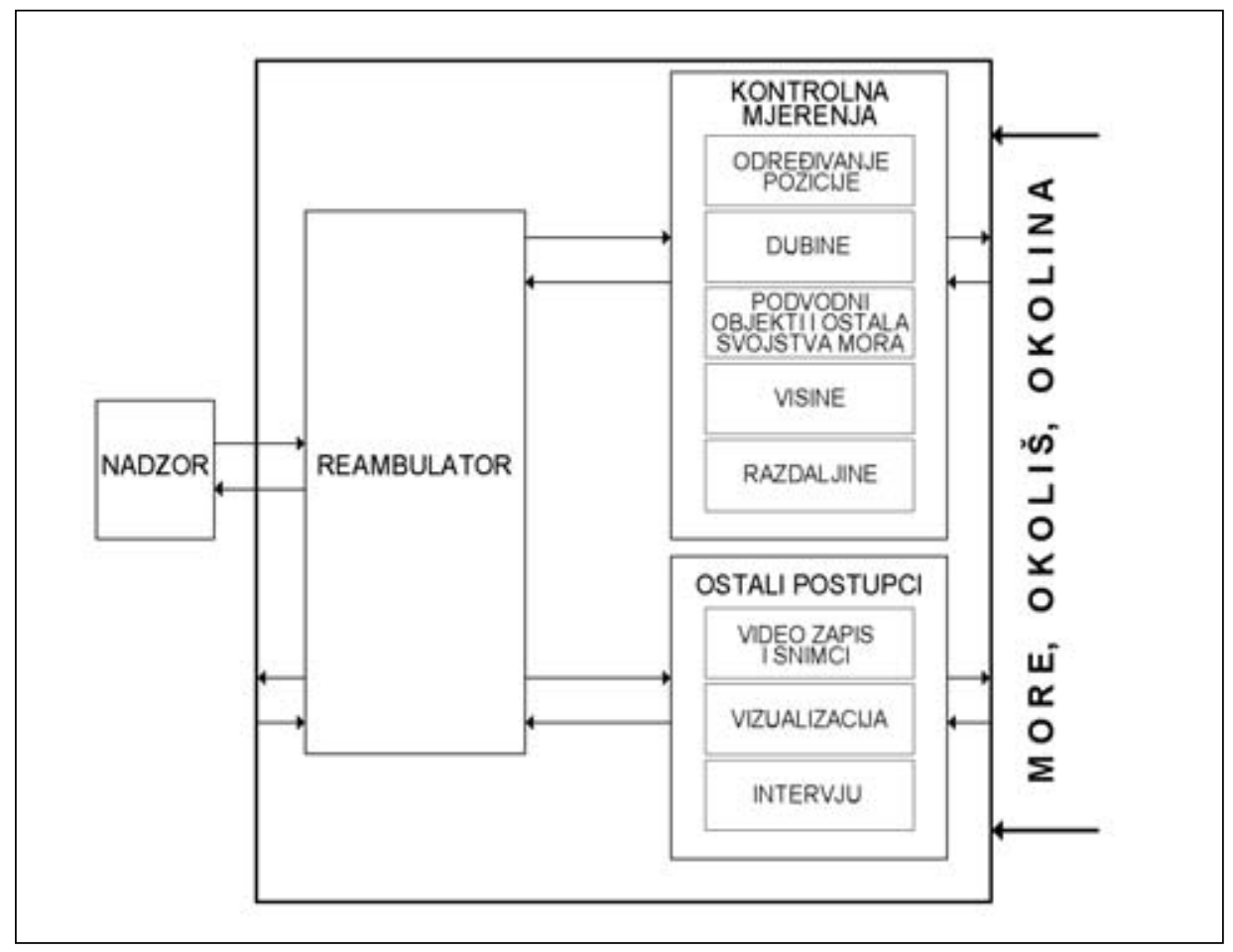

Sl. 4. Model radnih postupaka u reambulaciji

Fig. 4 Model of work procedures in revision 


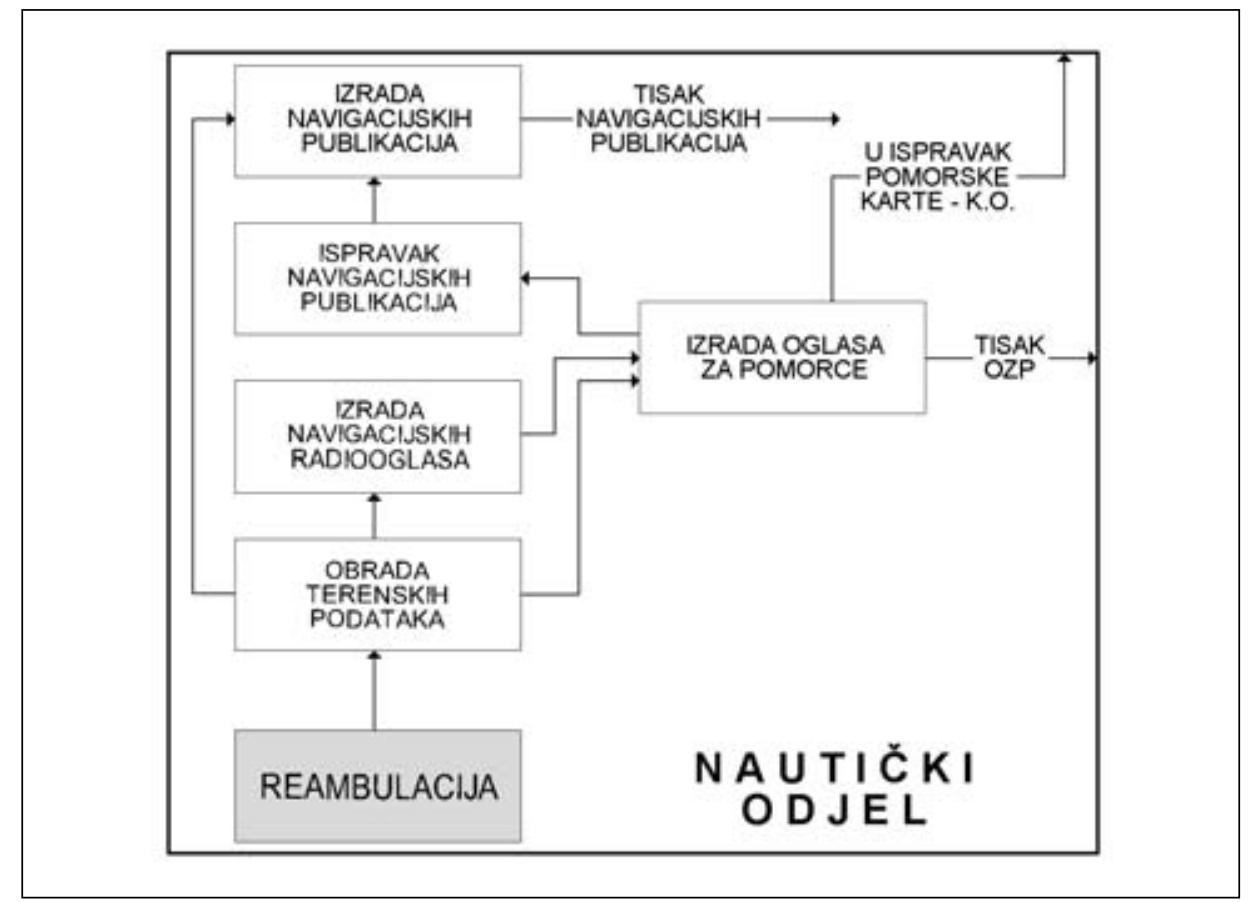

S1. 5. Glavni procesi u djelatnosti nautičkih odjela, odsjeka ili ureda hidrografskih služba i reambulacija

Fig. 5 Major processes in the activities of nautical departments or hydrographic organization offices and revision

reambulacijom, uspoređuju se s postojećim podacima i prema potrebi ispravljaju. Postupci hidrografskih služba, koji se mogu smatrati klasičnom reambulacijom nisu određeni normom. Stav autora je da se ne uočavaju kao važan element u procesu izrade i održavanja pomorskih karata i navigacijskih publikacija.

Mišljenje autora je da reambulacija mora, osim hidrografske izmjere, u djelatnim procesima hidrografskih služba zauzeti poziciju metode prikupljanja podataka za održavanje pomorskih karata i navigacijskih publikacija, te za korištenje tih podataka u svakodnevnoj djelatnosti (sl. 5). Informacijska sigurnost plovidbe temeljna je djelatnost nautičkih odjela, odsjeka ili ureda hidrografskih služba. Budući se reambulacija odnosi na podatke za održavanje, čini se opravdanim da planiranje i provedbu reambulacije obavljaju nautički odjeli, odsjeci ili uredi hidrografskih služba.

Valja zauzeti stajalište prema kojemu je točan podatak za održavanje pomorskih karata i navigacijskih publikacija jedino podatak objavljen u službenim publikacijama dobiven isključivo hidrografskom izmjerom i/ili reambulacijom. Reambulacija povećava čestoću i točnost podataka za održavanje pomorskih karata i navigacijskih publikacija. U životnom vijeku pomorske karte i navigacijske publikacije, reambulacija predstavlja postupak koji povećava točnost informacijskog sadržaja.

Za razliku od skupe i rijetke hidrografske izmjere, reambulaciji kao isplatljivijoj metodi, koja se primjenjuje u djelatnostima hidrografskih služba, valja odrediti čestoću provedbe. 


\section{ČESTOĆA PROVEDBE REAMBULACIJSKOG POSTUPKA}

Razvitkom novih (digitalnih) tehnologija u izradi pomorskih karata i navigacijskih publikacija, korištenjem satelitskih navigacijskih sustava pri navigaciji (N. Ackroyd i R. Lorimer, 1994.), točnost pomorskih karata i navigacijskih publikacija, te točnost u vođenju broda, podiže se na višu razinu. Povećanjem ove razine uočavaju se pogreške koje se ranije nije uočavalo, ili ih se pak zanemarivalo. Danas se one ne mogu zanemariti. Tako npr. u Republici Hrvatskoj, usporedba postojećih i prikupljenih informacija, te načina prikupljanja (kroz projekte PNP 1 i PNP 2 [Povjerljivi navigacijski priručnici], ADRIA I i JADRAN) ${ }^{5}$, upućuje na različnosti i manjkavosti u prikazu entiteta na pomorskim kartama i u navigacijskim publikacijama. Ona se može umanjiti redovitom primjenom reambulacijskih procesa i postupaka.

U morskim plovidbenim područjima, promjene se neprekidno događaju. Za hidrografske službe promjene su rezultat poznatih i nepoznatih djelatnosti raznih prirodnih i ljudskih čimbenika. Nepoznate djelatnosti imaju obilježja slučajnih procesa i mijenjaju značenje entiteta prikazanih na pomorskim kartama i u navigacijskim publikacijama. Poznate pak aktivnosti u morskim plovidbenim područjima odnose se na one o kojima se hidrografske službe redovito izvješćuje, ili ih same provode.

Pomorska karta i navigacijska publikacija moraju predstavljati stvarnost. One su odgovarajući model stvarnosti. S porastom čestoće provođenja reambulacije, povećava se točnost informacijskog sadržaja na pomorskim kartama i u navigacijskim publikacijama. Teoretski, reambulaciju bi valjalo provoditi što češće. S razine hidrografskih služba, na čestoću pokretanja reambulacijskog postupka utječu materijalne mogućnosti u određenom vremenskom razdoblju i ciljna točnost.

Hidrografskim službama cilj je proizvoditi maksimalno točne pomorske karte i navigacijske publikacije (Katalog, 1998.), a reambulacijom se prikupljaju podaci za njihovo održavanje, kao i za druge potrebe hidrografskih služba (zahtjevi vojnih vlasti, privrede, športskih djelatnosti i drugog).

\section{Redovita reambulacija i njezina čestoća}

Predlaže se da se redovita reambulacija provodi: prema godišnjemu planu, prije tiska nove pomorske karte ili navigacijske publikacije, kada je informacijski sadržaj pomorske karte ili navigacijske publikacije zagušen i kada točnost nije zadovoljavajuća.

Prema godišnjem planu, reambulacija se provodi sukladno s materijalnim mogućnostima hidrografske službe.

Novo izdanje pomorske karte i navigacijske publikacije nastaje isključivo nakon napravljene hidrografske izmjere. Od zadnje hidrografske izmjere, pa do objavljivanja novog izdanja pomorskih karata i navigacijskih publikacija, kod svih hidrografskih služba prođe stanovito vrijeme. ${ }^{6} \mathrm{U}$ tom vremenu događaju se promjene stvarnog stanja. Te promjene hidrografske službe ne bilježe, ili ih djelomice bilježe. Stoga, u cilju postizanja najvišeg stupnja točnosti u trenutku pokretanja novih izdanja, prije tiska valja pokrenuti reambulacijski postupak. 
Na to, u kojim područjima valja povećati čestoću reambulacije, a u kojima ju smanjiti ili uopće ne provoditi, utječe i ukupan broj prikazanih podatka za održavanje na pomorskoj karti i/ili navigacijskoj publikaciji, tj. gustoća podatka za održavanje (Go) i stanje njihove točnosti. Predlaže se informacijski sadržaj pomorskih karata i navigacijskih publikacija smatrati zagušenim ili neupotrebljivim kad je Go $>10 \%$. Na ovaj odnos upućuje iskustvo, ali ga još valja provjeriti u praksi.

Točnost informacijskog sadržaja pomorske karte i navigacijske publikacije određuje se koeficijentom točnosti (St), (Kasum, 2002.). Valja zauzeti stajalište da je i jedan netočan ili dvojben podatak dostatan za pokretanje reambulacije. Dakle, jednim od uvjeta za njezino pokretanje, drži se vrijednost $S_{t} \geq$ I. Nije nužna reambulacija na terenu, već upiti upravnim tijelima temeljem tipskih obrazaca za reambulaciju.

Plovidbena područja razlikuju se prema važnosti, sukladno prethodnoj hidrografskoj izmjeri. Očekuje se da područja iste važnosti za plovidbu pružaju i jednaku sigurnost plovidbe. Reambulacijom se obavljaju kontrolna mjerenja u područjima u kojima već obavilo se hidrografsku izmjeru. Stoga se i područja iste važnosti u reambulaciji određuju sukladno područjima prethodne hidrografske izmjere.

Svi informacijski sadržaji pojedine pomorske karte sa stajališta sigurnosti plovidbe, nisu jednako vrijedni. Svaka pomorska karta i navigacijska publikacija nisu jednako važne. Valja razvrstati pomorske karte i navigacijske publikacije prema: koeficijentu površinske opterećenosti karte (Kp), gustoći karte (Gk) i informacijskoj gustoći (Ig), (Kasum, 2002.).

Predlaže se pomorske karte i navigacijske publikacije kod kojih je Kp $<10$ \%, zbog krupnog mjerila i informacijskog sadržaja koji pružaju, držati manje važnima.

Povoljna gustoća karte (Gk) u djelatnostima raznih hidrografskih služba, određuje se različito. Stoga se pomorske karte za isto područje i u istom mjerilu, ali različitih izdavača, razlikuju prema vrsti i gustoći prikazanih entiteta.

Stoga u djelatnosti hidrografskih služba valja koristiti mjeru informacijske gustoće karte (Ig), pa različitim mjerilima pomorskih karata pridružiti odgovarajuću informacijsku gustoću (Kasum, 2002).

Uzevši u obzir predložene čimbenike, predlaže se algoritam za određivanja vrste i čestoće redovite reambulacije (Kasum, 2002.). Algoritam pokazuje u kojim se uvjetima reambulacija pokreće ili u slučaju automatiziranog procesa, kada i u kojim uvjetima dolazi poticaj pokretanja. Algoritam se može primijeniti za reambulaciju na pomorskim kartama i navigacijskim publikacijama, koje su tiskane temeljem podataka iz hidrografske izmjere, a poduzeta je poslije 1998., jer se novi IHO standardi (SP-44) primjenjuju od te godine.

\section{Izvanredna reambulacija i njezina čestoća}

Izvanredna reambulacija provodi se ako se: nije predvidjela planom, ne zahtijeva veća točnost i zahtijeva više podataka.

Hidrografske službe u svojoj redovitoj djelatnosti, zainteresiranim strankama iz područja privrednih i neprivrednih djelatnosti, pružaju razne hidrometeorološke podatke, 
koje se nije obuhvatilo, ili ih se samo djelomice obuhvatilo informacijskim sadržajem na pomorskim kartama i u navigacijskim publikacijama.

U tim slučajevima zahtijeva se veća točnost ili više podataka. Reambulaciju se nije predvidjelo planom, pa se drži izvanrednom reambulacijom. U ovim slučajevima, čestoća pokretanja postupka izvanredne reambulacije izravno ovisi o zahtjevu stranke.

\section{ZAKLJUČAK}

Reambulacija je postupak prikupljanja, analize, odabira i obrade pomorskih sigurnosnih informacija i podataka o morskim plovidbenim područjima, radi održavanja pomorskih karata i navigacijskih publikacija. Rezultati reambulacije (kontrolnih mjerenja) su reambulacijski podaci. Služe isključivo održavanju pomorskih karata i navigacijskih publikacija, te za druge potrebe hidrografskih služba. Reambulacija ne mijenja niti može zamijeniti hidrografsku izmjeru. U prvom redu odnosi se na provjeravanje točnosti i usuglašenosti podataka za održavanje pomorskih karata i navigacijskih publikacija nakon hidrografske izmjere i drugih postupaka u djelatnosti hidrografskih služba (zahtjevi vojnih vlasti, privrede, športskih djelatnosti i drugog), kada je utjecaj stvarnog stanja toliki da ju valja provesti.

Rezultat postupaka reambulacije nije uvijek ispravljanje ili potvrda točnosti podataka, već može rezultirati i uočavanjem potrebe za novom hidrografskom izmjerom. Točnim podacima za održavanje valja smatrati one, koji su prikupljeni hidrografskom izmjerom i/ili reambulacijom. Postupkom reambulacije, prema predloženom modelu radnih postupaka i algoritmu za određivanje vrste reambulacije i čestoće redovite reambulacije, nesuglasnost između stvarnosti i informacijskog sadržaja pomorskih karata i navigacijskih publikacija, svodi se na znatno manju mjeru (Kasum, 2002.).

Doprinos ovog rada jesu prijedlozi za suvremeniji organizacijski pristup pokretanju i obavljanju reambulacijskih postupaka. Oni se odnose na određivanje i označavanje geodetskih točaka namijenjenih reambulaciji, pokretanje izvanrednih reambulacija $u$ područjima u kojima se intenzivnije mijenja stvarno stanje okoliša, reorganizaciju unutar hidrografskih služba glede povećanja stupnja djelotvornosti i tehničke opremljenosti sa svrhom prikupljanja većeg broja podataka.

\section{POZIVNE BILJEŠKE}

1. Reambulacijom se provjeravaju podaci koji se uglavnom nalaze na obalnoj crti. Moguć je pristup s kopna uz korištenje različitih prometnih sredstava, pa hidrografski brod nije nužno potreban, osim uz krajnje nepristupačnu obalu.

2. Analiziralo se informacijski sadržaj oglasa za pomorce: Admiralty Notices to Mariners (Britanski hidrografski odjel), Notices to Mariners, (Hidrografski ured SAD-a) i Oglasa za pomorce (Hrvatski hidrografski institut) za razdoblje od 1994 do 1998. 
Zlatimir Bićanić, Josip Kasum i Zvonko Gržetić - Prilog unapređenju postupaka za održavanje Pomorskih karata i navigacijskih publikacija

3. Hidrograf je općeniti naziv u hidrografskim službama za osobe zvanja dipl. ing. Geodezije, koje se uključuje u postupak hidrografske izmjere. Zbog specifičnosti posla kojeg obavljaju, dužni su polagati stručne ispite kojima potvrđuju svoju stručnost i stječu ovlaštenje za obavljanje posla (Ministarstvo pravosuđa, Hrvatski hidrografski institut, Geodetska uprava).

4. Tako npr. u Republici Hrvatskoj Zakon o građenju (Narodne novine 77/1992., 82/1992., 26/1993. i 33/1995.) uređuje odnose u svezi izgradnje, građevinske dozvole, obveze javljanja promjena, čestoće djelovanja građevinskih inspekcija i sl.

5. PNP 1 i PNP 2 su znanstvenoistraživački projekti HHI-a pod punim nazivom: Povjerljivi navigacijski priručnik 1 i 2, a izradilo ih se za potrebe Ministarstva obrane Republike Hrvatske (1995 do 1998.). ADRIA 1 je znanstvenoistraživački projekt HHI-a pod punim nazivom: Hidrografsko-geološke, hidronavigacijske, klimatološke, oceanografske i ekološke značajke akvatorija područja polaganja optičkog kabela (Jadransko more - Istočna obala). Izradilo ga se u suradnji s Ministarstvom pomorstva, prometa i veza, HPT-om i Deutsche Bundespost Telekomom, u razdoblju od 1993 do 1995. JADRAN je znanstvenoistraživački projekt HHI-a pod punim nazivom: Sustavno istraživanje Jadranskog mora kao osnova održivog razvitka Republike Hrvatske. Izvodi se uz potporu Ministarstva znanosti i tehnologije Republike Hrvatske (1998. i dalje).

6. Približno jedan, do tri i više mjeseci, ovisno o veličini područja koje se obuhvatilo izmjerom, te tehnologiji izrade pomorskih karata i navigacijskih publikacija.

\section{LITERATURA}

Ackroyd, N. \& R. Lorimer 1942.: Global Navigation a GPS users guide, LLP, London.

Adams, K. T. 1942.: Hydrographic Manual, Washigton.

Buljan, M. i M. Zore-Armanda 1971.: Osnovi oceanografije i pomorske meteorologije, Institut za oceanografiju i ribarstvo, Split, 14-22.

Jovanović, B. 1975.: Prilog izučavanju metoda određivanja podvodnog reljefa, magistarski rad, Sveučilište u Zagrebu, Geodetski odjel, Zagreb, 169 pp.

Kasum, J. 2002.: Doprinos optimizaciji reambulacije primjenom elektroničkih i informatičkih tehnologija, doktorska disertacija, Sveučilište u Rijeci, Pomorski fakultet, Rijeka, 7-8, 24-28, 43, 55-60.

Kiely, E. 1979.: Surveying Instruments: Their History, Carben Surveying Reprints, Columbus.

Klaić, B. 1987.: Rječnik stranih riječi, NZMH Zagreb, Zagreb, 1137 pp.

Oshima, S. 1998.: Where are National Hydrographic Authorities Heading for? Hydro International.

IHO (International Hidrigraphic Organization; 1994.): Resolution of the IHO, Part F, Monaco.

IHO (International Hidrigraphic Organization; 1998.): Special Publication, No. 44, 4. izdanje, Monaco.

Pomorski leksikon 1990., Leksikografski zavod Miroslav Krleža, Zagreb, 241 pp.

VHDL Modeling Terminology and Taxonomy, RASSP Taxonomy Working Group (RTWG), inačica 3.1, SAD, 2000.

Katalog pomorskih karata i navigacijskih publikacija, Hrvatski hidrografski institut, Split, 1998. 


\title{
Contributions to Advancement of Updating Procedures of Sea Charts and Sea Publlications
}

\author{
by \\ Zlatimir Bićanić, Josip Kasum and Zvonko Gržetić
}

The subject of this paper is revision, a process which is initiated in order to check the degree of concordance of information on charts and nautical publications with the real situation in nature. It is a set of procedures in compiling the maritime safety information and the data on navigational sea areas. Revision includes field works and activities in the hydrographic organization. Field works are carried out within exclusive coverage of the hydrographic survey, whereas activities in hydrographic organizations include analyses and processing of the results obtained from revision. Through revision procedures, the differences between reality and information content of charts and nautical publications can be reduced to a minimum. This paper aims to find the way to increase the degree of concordance of the data represented on charts and nautical publications with the real situation in nature, as well as between themselves.

The whole process is categorized. First category of revision applies to ports, approach channels, recommended sea routes, inland channels, and coastal areas with heavy maritime traffic. Second category includes the sea areas with depths below $200 \mathrm{~m}$, and the third one those with depths greater than $200 \mathrm{~m}$.

It is not possible to publish the new edition of a chart or nautical publication based on the results of the revision control measurements, as they cannot replace the hydrographic survey. Revision results serve only for collecting the data in order to keep charts and nautical publications up to date. Not only does revision necessarily result in correcting the data or confirming their accuracy, but it can also reveal the need for a new hydrographic survey.

Information for keeping charts and publications up to date are numerous and diverse, yet not all the data represented on charts and nautical publications are equally important for navigational safety. The degree of navigational importance is assessed by the reviser, and such assessments of data/set of data are important for making management decisions.

Most important information for keeping charts and nautical publications accurate are obtained from determining and measuring of positions, depths, some hydrological properties of the sea water, heights and distances.

In the control measurements of depths (sea depths) in ports and boat harbours, in the places where great depth variations are dangerous for navigational safety (depths alongside quays, pierheads, etc.), it is proposed to fix and mark revision points, similarly as minor control points. The following term of reference is proposed: Revision point is a permanently marked point on Earth's surface with determined coordinates and height above sea level or depth. Revision point is used only for revision. This provides exact position where control depth measurement has been carried out, for the purpose of a repeated measurement at the same point.

It is also proposed to carry out the revision of the area after laying of cables, pipelines or similar installations in the sea. The aim is to ensure accordance of cable or pipeline position with the real situation and the data on charts and nautical publications. 
Charts and nautical publications must represent the real situation. Accuracy of information content of charts and nautical publications is increased with the frequency of revisions. Theoretically, revision should be carried out as frequently as possible.

New edition of chart or nautical publication is issued only after a hydrographic survey has been carried out. Up to its printing a lot of changes occur, so that before printing a regular revision procedure must be carried out, in order to obtain maximum accuracy.

In their regular activities, hydrographic organizations provide to their interested clients numerous information that are not included on charts and nautical publications at all, or just partly.

In such cases a higher accuracy or greater quantity of information is required. This is achieved through additional revision, and the frequency of starting such procedure depends on client's request.

Primljeno (Received): 10 - 12 - 2002

Prihvaćeno (Accepted): 25 - 10 - 2005

Zlatimir Bićanić, dr.sc., red.prof., Pomorski fakultat u osnivanju, Zrinjsko Frankopanska 38, 21000 Split, Hrvatska/Croatia

Josip Kasum, dr. sc., Pomorski fakultet u osnivanju, Zrinjsko Frankopanska 161, 21000 Split, Hrvatska/Croatia

Zvonko Gržetić, dr. sc., doc., Hrvatski hidrografski institut, Zrinjsko Frankopanska 161, 21000 Split, Hrvatska/Croatia 